\title{
Direct Incorporation of Ginger and Oregano Antioxidants in Canola Oil
}

\author{
Andressa H. A. Grabsk, Alexandre S. Avincola, Thiago Claus, Carla Porto, \\ Jesuí V. Visentainer and Eduardo J. Pilau* \\ Departamento de Química, Universidade Estadual de Maringá (UEM), \\ 87020-900 Maringá-PR, Brazil
}

\begin{abstract}
Antioxidants are used to increase the shelf life of food and oils. The most common extraction method of antioxidants from natural sources is the use of organic solvents, like methanol and ethanol. Evaporation of all the organic solvent is necessary to prevent health diseases. In this study, we present a new "organic solvent-free" method to extract antioxidants, which uses canola oil as extraction solvent to incorporate natural antioxidants from oregano and ginger without the use of organic solvent. The oil solvent extraction capacity was assessed by assays of oxygen radical absorbance capacity method for hydrophilic $\left(721.9 \pm 10.5\right.$ and $89.0 \pm 2.5 \mu \mathrm{mol} \mathrm{TE} \mathrm{g}{ }^{-1}$ to canola oil with oregano and ginger, respectively) and lipophilic (118.8 \pm 7.4 and $48.2 \pm 9.7 \mu \mathrm{mol} \mathrm{TE} \mathrm{g}{ }^{-1}$ to canola oil with oregano and ginger, respectively) compounds, oxidation test (Oxitest $\left.{ }^{\circledR}\right)(1,434$ and 1,018 minutes to canola oil with oregano and ginger, respectively) and thiobarbituric acid reactive substances $\left(0.01 \pm 0.02\right.$ and $0.11 \pm 0.06 \mathrm{mg} \mathrm{MA} \mathrm{g}^{-1}$ to canola oil with oregano and ginger, respectively). Results provide evidence of the efficiency of canola oil as antioxidants extractor. Nine antioxidant compounds from canola oil incorporated with antioxidants compounds were identified using high performance liquid chromatography tandem mass spectrometry.
\end{abstract}

Keywords: antioxidant capacity, high-performance liquid chromatography-electrospray ionization mass spectrometry, green chemistry, solvent free

\section{Introduction}

The use of antioxidants is the simplest method to reduce fat oxidation in food and oils. ${ }^{1}$ In most cases, synthetic antioxidants such as butylated hydroxyanisole (BHA), butylated hydroxytoluene (BHT), propyl gallate (PG) and tert-butylhydroquinone (TBHQ) are used as additives. However, there is evidence that synthetic antioxidants have harmful effects on human health. ${ }^{2,3}$ Because of this, research for suitable natural sources of antioxidants for use in the food and oil industries have been performed. ${ }^{4}$

Natural antioxidants from plants have many advantages when compared to synthetic antioxidants. ${ }^{1}$ Overall, natural antioxidants have functional and sensory properties, are considered safe, and have greater acceptability by the consumers. ${ }^{1}$ On the other hand, different organic solvents such as methanol, ethanol and acetone are used to extract antioxidants from fruits, vegetables and other types of foods. These solvents have hazardous and toxic properties and can cause adverse health effects. ${ }^{5}$

*e-mail: epilau@gmail.com
This study aimed to develop a new "organic solventfree" method to extract antioxidants from oregano and ginger using canola oil. The antioxidant capacity from the canola oil with spices was evaluated by oxygen radical absorbance capacity method (ORAC), using the fluorescein (FL) decay curve $\left(\mathrm{ORAC}_{\mathrm{FL}}\right)$ of hydrophilic compounds $\left(\mathrm{H}-\mathrm{ORAC} \mathrm{C}_{\mathrm{FL}}\right)$ and lipophilic compounds $\left(\mathrm{L}-\mathrm{ORAC} \mathrm{FL}_{\mathrm{FL}}\right)$. The lipid oxidation of the samples was measured by two different methods: a new method known as Oxitest, and by thiobarbituric acid reactive substances (TBARS) assay. Antioxidants compounds incorporated in the canola oil were identified by high performance liquid chromatography (HPLC) tandem mass spectrometry using a fingerprint analysis (MS) and daughters scan mode (MS/MS). Furthermore, we evaluated the canola oil extraction efficiency compared to methanolic extraction of spices.

\section{Experimental}

Sample preparation

Canola oil was kindly supplied by Cooperativa Agroindustrial de Maringá (Cocamar, Brazil), and ginger 
rhizomes and dried oregano leaves were purchased at a local market in Maringá (Brazil). Ginger rhizome was dried in a drying oven at $50{ }^{\circ} \mathrm{C}$ for $24 \mathrm{~h}$. Both spices were grounded and sieved in a 35 mesh. Ginger or oregano was added individually to canola oil at three different concentrations: $2.5,5.0$, and $10.0 \mathrm{~g}$ in $100.0 \mathrm{~g}$ of canola oil. Samples were agitated in magnetic stirrer for $1 \mathrm{~h}$ and thermostatic bath at $30{ }^{\circ} \mathrm{C}$ to incorporate antioxidants in the canola oil. The samples were stored at $8{ }^{\circ} \mathrm{C}$ in dark until analyses were performed.

$\mathrm{ORAC}_{\mathrm{FL}}$ assay

L-ORAC $\mathrm{FL}_{\mathrm{FL}}$ and $\mathrm{H}-\mathrm{ORAC}_{\mathrm{FL}}$ were determined separately as described by $\mathrm{Wu}$ et al. ${ }^{6}$ with modifications. $\mathrm{ORAC}_{\mathrm{FL}}$ analysis was conducted in a microplate reader (Victor X4, PerkinElmer, USA) with fluorescence filters with excitation and emission wavelengths of 485 and $535 \mathrm{~nm}$, respectively. In each recipient, inside the microplate, $20 \mu \mathrm{L}$ of sample extract and $200 \mu \mathrm{L}$ of $\mathrm{FL}\left(12.0 \mathrm{mmol} \mathrm{L}^{-1}\right.$ in potassium phosphate buffer $75.0 \mathrm{mmol} \mathrm{L}^{-1}, \mathrm{pH}$ 7.0) were added. The microplate was heated to $37^{\circ} \mathrm{C}$ for $5 \mathrm{~min}$, and $75 \mu \mathrm{L}$ of 2,2'-azobis (2-amidinopropane) dihydrochloride (AAPH) in potassium phosphate buffer $75.0 \mathrm{mmol} \mathrm{L}^{-1}, \mathrm{pH} 7.0$ (63.5 mmol L $\mathrm{m}^{-1}$ to lipophilic assay and $32.0 \mathrm{mmol} \mathrm{L}^{-1}$ to hydrophilic assay), was added. Fluorescence was immediately measured after addition of radical and the following measurements were obtained at intervals of $1 \mathrm{~min}$, for $30 \mathrm{~min}$. A blank with only phosphate buffer was used and the quantification was performed using linear regression $(y=a x+b)$ and coefficient of determination $\left(\mathrm{r}^{2}\right)$ between Trolox $(\mathrm{T})$ concentration $\left(5-50 \mu \mathrm{mol} \mathrm{T} \mathrm{L^{-1 }}\right)$ and the net area under the FL decay curve. ${ }^{7}$ The results are expressed in $\mu \mathrm{mol}$ Trolox equivalent per gram of sample

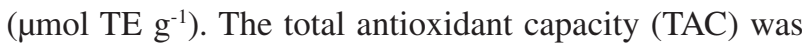
calculated by summing the $\mathrm{L}-\mathrm{ORAC} \mathrm{FL}_{\mathrm{FL}}$ and $\mathrm{H}-\mathrm{ORAC} \mathrm{F}_{\mathrm{FL}}$.

\section{Oxidation test}

Oxidation tests were performed as described by Verardo et $_{\text {al. }}{ }^{8}$ using Oxitest ${ }^{\circledR}$ (VelpScientifica, Usmate, Milan, Italy) and $5 \mathrm{~g}$ of each sample (oils incorporated with antioxidants). The Oxitest ${ }^{\circledR}$ assay determines induction periods (IPs) to detect rancidity of lipids, by accelerating the oxidation process using high temperatures (until $110^{\circ} \mathrm{C}$ ) and high pressure ultra-pure oxygen. The IPs of the samples were obtained by two-tangent method. When a compound which delays oxidation is added to the system, latency to a measurable decrease in oxygen pressure will increase. ${ }^{4}$ Temperature was set to $90{ }^{\circ} \mathrm{C}$ and oxygen pressure to $600 \mathrm{kPa}$ (99.9999\% purity). The oxidation of canola oil alone (control) was also evaluated.

\section{TBARS analysis}

The assays of TBARS was conducted according to the method described by Adolfo Lutz Institute Standards. ${ }^{9}$ Samples of canola oil (incorporated with antioxidants) were stored for 100 days at $4{ }^{\circ} \mathrm{C}$ and in dark prior to the analysis. Malonaldehyde (MA) solutions was prepared with 5 different concentrations (3-200 $\mathrm{mg} \mathrm{MA} \mathrm{L}^{-1}$ ) and a standard curve was prepared. The concentrations of MA in the samples were plotted and were expressed in $\mathrm{mg}$ malonaldehyde per gram of sample ( $\left.\mathrm{mg} \mathrm{MA} \mathrm{g}^{-1}\right)$.

\section{Preparation of samples for HPLC analysis}

$0.25 \mathrm{~g}$ of ginger rhizomes and oregano leaves were submitted to extraction procedure in $6.3 \mathrm{~mL}$ (equivalent to $5 \mathrm{~g}$ ) of methanol, under magnetic agitation for $1 \mathrm{~h}$ and thermostatic bath at $30^{\circ} \mathrm{C} .5 .0 \mathrm{~g}$ of canola oil (incorporated with antioxidants) was mixed to $2 \mathrm{~mL}$ of methanol ( 3 times) to obtain the methanolic extract. A control was prepared using canola oil (without spices) extracted with methanol. The samples were shaken and centrifuged for $5 \mathrm{~min}$. The solvent of all extracts was evaporated under nitrogen flow.

\section{HPLC-MS/MS instrumentation}

Determination of antioxidant compounds in oregano and ginger extracts were carried out using a Waters $1525 \mu$ (Binary HPLC Pump, USA) system coupled to a mass spectrometry Quattro micro API Waters (Beverly, USA) consisting of a triple quadrupole mass spectrometer equipped with electrospray ionization source. The chromatographic separation was performed on a Waters Symmetry ${ }^{\circledR}$ C18 column $(3.6 \mu \mathrm{m}, 4.6 \times 75 \mathrm{~mm})$ at room temperature. Solvent A was water/0.1\% formic acid (v/v) and solvent B was acetonitrile/0.1\% formic acid (v/v). The gradient was as follows: $0-8 \mathrm{~min}, 2-50 \% \mathrm{~B} ; 8-11 \mathrm{~min}$, 50-70\% B; 11-13 min, 70-98\% B; 13-15 min, 98\% B; $15-20 \mathrm{~min}, 98-2 \% \mathrm{~B}$, at a flow rate of $0.5 \mathrm{~mL} \mathrm{~min}^{-1}$.

The MS determination was performed in positive electrospray mode. The conditions were as follows: capillary temperature of $150{ }^{\circ} \mathrm{C}$; dessolvation temperature of $400{ }^{\circ} \mathrm{C}$, capillary voltage of $2.0 \mathrm{kV}$, cone voltage of $25 \mathrm{~V}$. Argon at $0.32 \mathrm{~Pa}$ was used for collision-induced dissociation at collision energy of 10-35 eV.

The antioxidant compounds from canola oils after oregano and ginger antioxidants incorporation were identified using MS/MS fragment ions. The fragmentation patterns of these compounds have been previously identified in other works and database search, such as MassBank and mzCloud. ${ }^{10-14}$ 


\section{Statistics}

Statistical analysis was carried out using the Tukey's test (Statistica) with the statistical significance level fixed at $p<0.05$. The data are expressed as means \pm standard deviation for samples in triplicate.

\section{Results and Discussion}

ORAC is one of the most popular methods used to evaluate the antioxidant capacities of oils. ${ }^{7}$ The total antioxidant capacity values for concentrations of 5.0 and $10.0 \mathrm{~g}$ of oregano incorporated in canola oil (Table 1) are similar and significantly higher than values for total antioxidant capacity of $2.5 \mathrm{~g}$ of oregano incorporated in $100 \mathrm{~g}$ of canola oil. In addition, values for total antioxidant capacity concentrations of 5.0 and $10.0 \mathrm{~g}$ are similar $(p>0.05)$. This is probably due to saturation of canola oil when $5.0 \mathrm{~g}$ of spices was used. Similar assumption may be extrapolated for the canola oil containing ginger (Table 2). Therefore, the optimum concentration used in subsequent experiments was $5.0 \mathrm{~g}$ spices in $100.0 \mathrm{~g}$ of canola oil. The antioxidant capacity of the canola oil containing oregano was higher than the antioxidant capacity of canola oil with ginger and the control, and both spices had higher antioxidant capacity than canola oil control. Furthermore, in the present study we were able to extract antioxidants from ginger and oregano using canola oil as solvent extractor without the use of any organic solvent extraction.

Oxitest is a new method used to evaluate the oxidative process of lipids. In this experiment, canola oils with ginger or oregano had greater protection against lipid oxidation compared to control (Figure 1). The IPs was greater for the canola oil incorporated with both spices compared
Table 1. Antioxidant capacity of canola oil incorporated with oregano antioxidants, analysed by the $\mathrm{ORAC}_{\mathrm{FL}}$ method

\begin{tabular}{|c|c|c|c|c|}
\hline Sample & $\begin{array}{c}\text { Amount of } \\
\text { spice per } \\
100 \mathrm{~g} \text { of oil / g }\end{array}$ & $\begin{array}{l}\mathrm{H}-\mathrm{ORAC} \mathrm{FL}_{\mathrm{FL}} / \\
\left(\mu \mathrm{mol} \mathrm{TE} \mathrm{g}^{-1}\right)\end{array}$ & $\begin{array}{c}\mathrm{L}^{-O R A C} \mathrm{FL}_{\mathrm{FL}} / \\
\left(\mu \mathrm{mol} \mathrm{TE} \mathrm{g} \mathrm{g}^{-1}\right)\end{array}$ & $\begin{array}{c}\text { TAC / } \\
\left(\mu \mathrm{mol} \mathrm{TE} \mathrm{g} g^{-1}\right)\end{array}$ \\
\hline Control & & $12.8 \pm 0.50$ & $1.3 \pm 0.1$ & $14.1 \pm 0.5$ \\
\hline \multirow[t]{3}{*}{ Oregano } & 2.5 & $439.7^{c} \pm 21.8$ & $120.7^{b} \pm 5.3$ & $560.4^{b} \pm 22.4$ \\
\hline & 5.0 & $712.9^{\mathrm{a}} \pm 10.5$ & $118.8^{\mathrm{b}} \pm 7.4$ & $831.7^{\mathrm{a}} \pm 12.8$ \\
\hline & 10.0 & $667.3^{b} \pm 14.6$ & $144.3^{\mathrm{a}} \pm 8.0$ & $811.6^{a} \pm 16.6$ \\
\hline
\end{tabular}

Average \pm standard deviation $(n=3)$. Means followed by different letters in the same column showed significant difference by Tukey's test $(p<0.05)$. TAC: total antioxidant capacity.

Table 2. Antioxidant capacity of canola oil incorporated with ginger antioxidants analysed, by the $\mathrm{ORAC}_{\mathrm{FL}}$ method

\begin{tabular}{|c|c|c|c|c|}
\hline Sample & $\begin{array}{c}\text { Amount of } \\
\text { spice per } \\
100 \mathrm{~g} \text { of oil / g }\end{array}$ & $\begin{array}{l}\mathrm{H}-\mathrm{ORAC} \\
(\mu \mathrm{FL}\end{array}$ & $\begin{array}{l}\text { L-ORAC }_{\mathrm{FL}} / \\
\left(\mu \mathrm{mol} \mathrm{TE} \mathrm{g}^{-1}\right)\end{array}$ & $\begin{array}{c}\text { TAC / } \\
\left(\mu \mathrm{mol} \mathrm{TE} \mathrm{g} \mathrm{g}^{-1}\right)\end{array}$ \\
\hline Control & & $12.8 \pm 0.50$ & $1.3 \pm 0.1$ & $14.1 \pm 0.5$ \\
\hline \multirow[t]{3}{*}{ Ginger } & 2.5 & $42.4^{\mathrm{b}} \pm 4.9$ & $30.4^{b} \pm 2.6$ & $72.8^{\mathrm{b}} \pm 5.5$ \\
\hline & 5.0 & $89.0^{\mathrm{a}} \pm 12.5$ & $48.2^{\mathrm{a}} \pm 9.7$ & $137.2^{\mathrm{a}} \pm 15.8$ \\
\hline & 10.0 & $78.9^{\mathrm{a}} \pm 9.8$ & $59.5^{\mathrm{a}} \pm 5.3$ & $138.4^{\mathrm{a}} \pm 11.1$ \\
\hline
\end{tabular}

Average \pm standard deviation $(n=3)$. Means followed by different letters in the same column showed significant difference by Tukey's test $(p<0.05)$. TAC: total antioxidant capacity.

to canola oil (control). The IP of canola oil with oregano was increased by approximately 811 minutes compared to IP of canola oil (623 minutes), and the IP of canola oil with ginger was increased by approximately 395 minutes compared to canola oil. Both spices provided protection to canola oil against lipid oxidation, however oregano was more efficient than ginger. These results provide evidence that the canola oil was a good solvent for the extraction of antioxidants and the extracted antioxidants delayed lipid oxidation, which is an intrinsic characteristic of

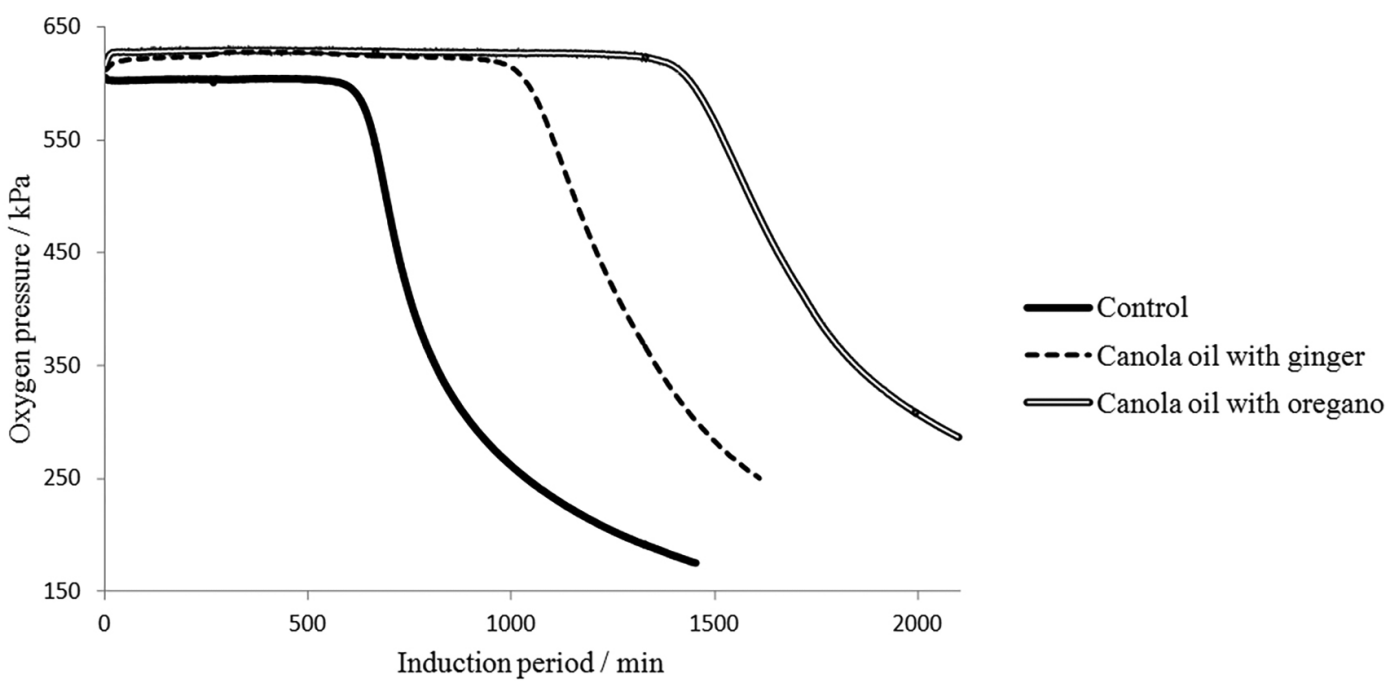

Figure 1. Curves obtained for the induction periods (Oxitest ${ }^{\circledR}$ ) for canola oil samples. 
antioxidants. The main antioxidants action mechanism is based on the donation of an active hydrogen atom from antioxidant ( $\mathrm{AH})$ to a free radicals ( $\mathrm{ROO}^{\circ}$ and $\left.\mathrm{R}^{\circ}\right)$. This donation stops the oxidation and after that antioxidants become radicals resonance stabilized $\left(\mathrm{A}^{*}\right)$, which are less active than those radicals they have neutralized (equations 1 and 2). ${ }^{15,16}$

$\mathrm{ROO}^{*}+\mathrm{AH} \rightarrow \mathrm{ROOH}+\mathrm{A}^{*}$

$\mathrm{R}^{\bullet}+\mathrm{AH} \rightarrow \mathrm{RH}+\mathrm{A}^{*}$

Thus, canola oil is a potential extractor solvent of antioxidants from oregano and ginger and these compounds inhibit the degradation of lipids.

One of the most common methods to measure lipid oxidation in foods is the quantification of malonaldehyde by reaction with 2-thiobarbituric acid, in the so-called TBA-reactive substances assay. All samples were stored in similar conditions for 100 days under refrigeration and protected from light. The action of antioxidants from oregano in canola oil was very impressive. Samples from canola oil with oregano had discrete oxidation, and canola oil alone (control) had ca. 20-fold increase in oxidation (Table 3). The canola oil with ginger also had protection against oxidation, but less efficient than canola oil with oregano (ca. 2-fold increase). Results of TBARS assay corroborate results obtained by $\mathrm{ORAC}_{\mathrm{FL}}$ and Oxitest ${ }^{\circledR}$ methods.

Table 3. Thiobarbituric acid reactive substances (TBARS) assay of canola oil control and canola oil with $5 \mathrm{~g}$ of spices in $100 \mathrm{~g}$ of canola oil

\begin{tabular}{lc}
\hline Sample & TBARS / $\left(\mathrm{mg} \mathrm{MA} \mathrm{g}^{-1}\right)$ \\
\hline Control & $0.20^{\mathrm{a}} \pm 0.06$ \\
Canola oil with oregano & $0.01^{\mathrm{c}} \pm 0.02$ \\
Canola oil with ginger & $0.11^{\mathrm{b}} \pm 0.06$ \\
\hline
\end{tabular}

Average \pm standard deviation $(n=3)$. Means followed by different letters in the same column showed significant difference by Tukey's test $(p<0.05)$.

Antioxidant compounds from oregano and ginger were identified by HPLC-MS analysis (Figure 2), and the efficiency of extraction using canola oil compared to methanol was assessed. The chromatograms of methanolic extracts of canola oil with oregano or ginger (Figures $2 \mathrm{a}$ and $2 \mathrm{~b}$, respectively) have a different profile (fingerprint) compared to the canola oil control (Figure 2c). This difference in chromatograms is probably from the incorporation of antioxidants from spices in canola oil in the solvent free process that was used.

The chromatographic profile of canola oil incorporated with antioxidants from either oregano (Figure 2a) or ginger (Figure 2b) was similar to the chromatograms of methanolic extracts of oregano (Figure 3a) or ginger (Figure 3b). HPLC-MS and HPLC-MS/MS analysis demonstrated that the incorporation of antioxidants directly in the canola oil provides similar results to the extraction carried out with methanol. Methanol is one of the most used solvents for antioxidant extraction, because it is cheap and reusable. However, it has hazardous and toxic properties, which can cause adverse health effects (e.g., intoxication, visual insufficiency and dermatitis). ${ }^{17}$ The methanol toxicity is due to the rate in which it is eliminated from the body, and also due to the toxicity of the products of its metabolic oxidation, formaldehyde and formic acid. ${ }^{18,19}$ Due to its toxicity, methanol extraction is not favored in the food industry. When employed, the solvent must be removed completely from the extract prior to its application in food products. ${ }^{17}$ Therefore, it can be suggested canola oil to be used as solvent extractor, as it was as good as methanol to extract antioxidants from oregano and ginger. This approach has many advantages compared to the extraction using organic solvent extraction, such as: reduction of environmental pollution; low cost; simplicity in the process and handling; high temperatures and multiple extractions are not necessary. ${ }^{17-20}$

The Figures 4 and 5 show the fragmentation spectrum of apigenin (an oregano antioxidant), and 6-shogaol (a ginger antioxidant), respectively.

Antioxidants from oregano and ginger incorporated in canola oil and identified by study of their fragmentation spectra, published data, and searches in MassBank and mzCloud databases, are described in Table 4. Oregano and ginger antioxidants belong to different classes. The constituents responsible for the antioxidant activity of ginger are compounds belonging to the gingerol family and its derivatives. ${ }^{10}$ Oregano has a variety of classes of antioxidants, such as phenolic acids, flavones, flavonols and flavonoids. ${ }^{21}$ The antioxidant capacity and antioxidant compounds are mainly affected by season and planting region factors. ${ }^{22}$

\section{Conclusions}

In this study, we successfully extracted antioxidants from oregano and ginger using canola oil as solvent extractor (i.e., solvent free), obtaining an oil with natural antioxidants, contributing to environmental sustainability and human health. The extraction efficiency is corroborated by assays of oxygen radical absorbance capacity method, oxidation test by Oxitest and thiobarbituric acid reactive substances. The results obtained using HPLC-MS and HPLC-MS/MS confirmed the efficiency of canola oil as solvent extractor to antioxidants compounds, as well as 
methanol. In addition, a total of 9 antioxidant compounds were identified from oregano and ginger. Therefore, oregano and ginger are great sources of antioxidant compounds that protect the canola oil against lipid oxidation.
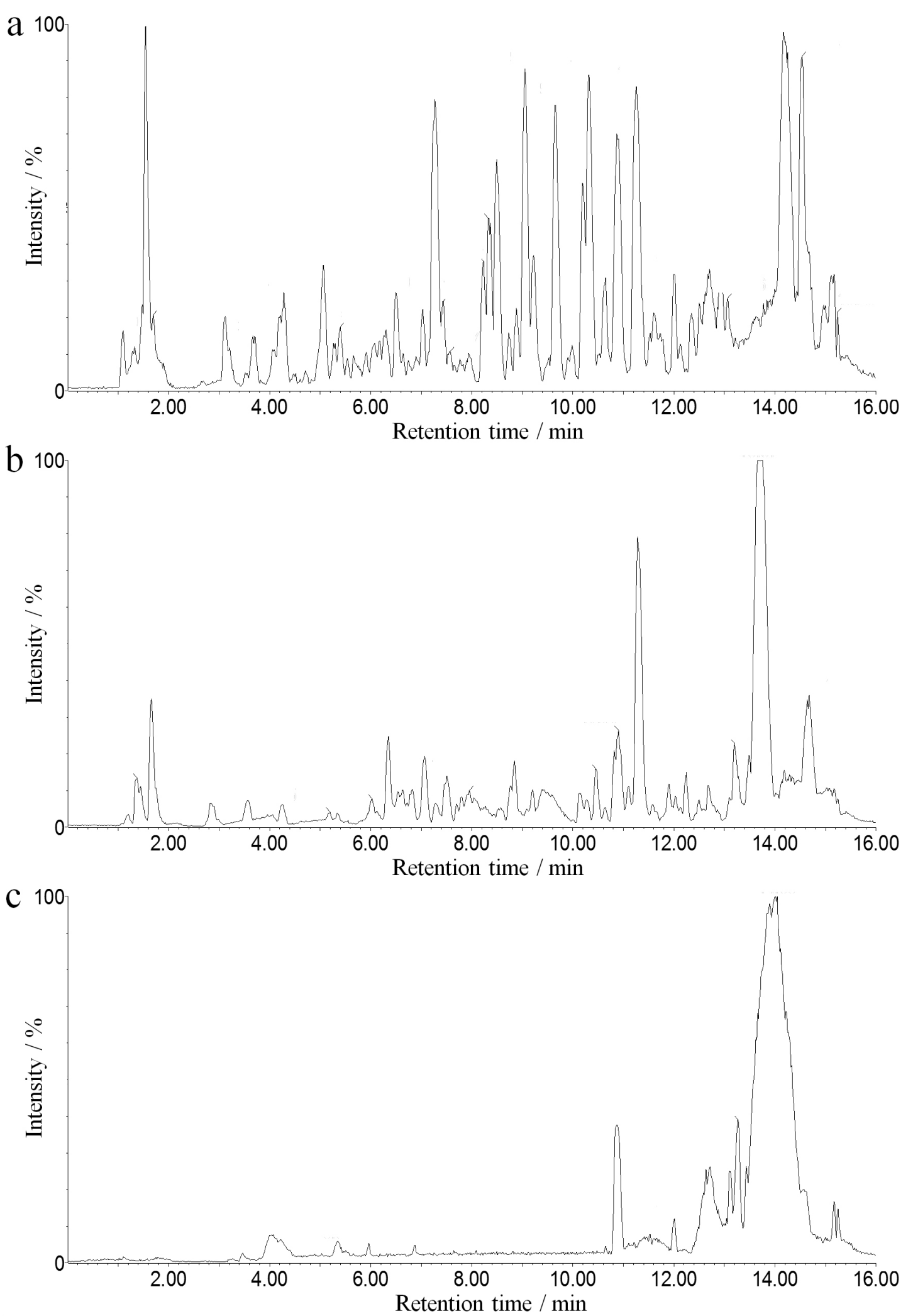

Figure 2. HPLC-ESI-MS analyses of methanolic extracts from: (a) canola oil with addition of oregano; (b) canola oil with addition of ginger; (c) control canola oil. 

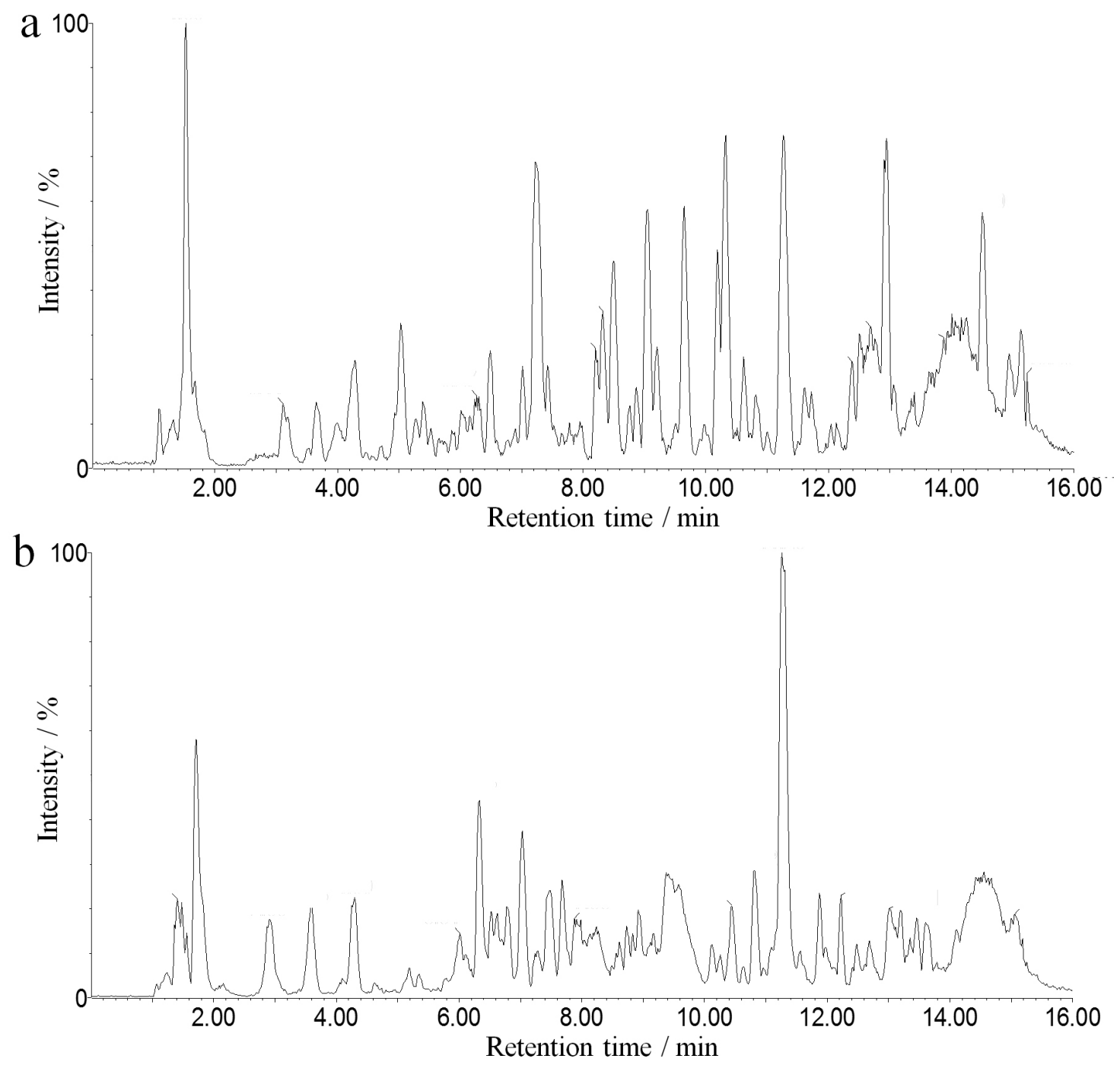

Figure 3. HPLC-ESI-MS analysis of methanolic extracts from: (a) oregano; (b) ginger.

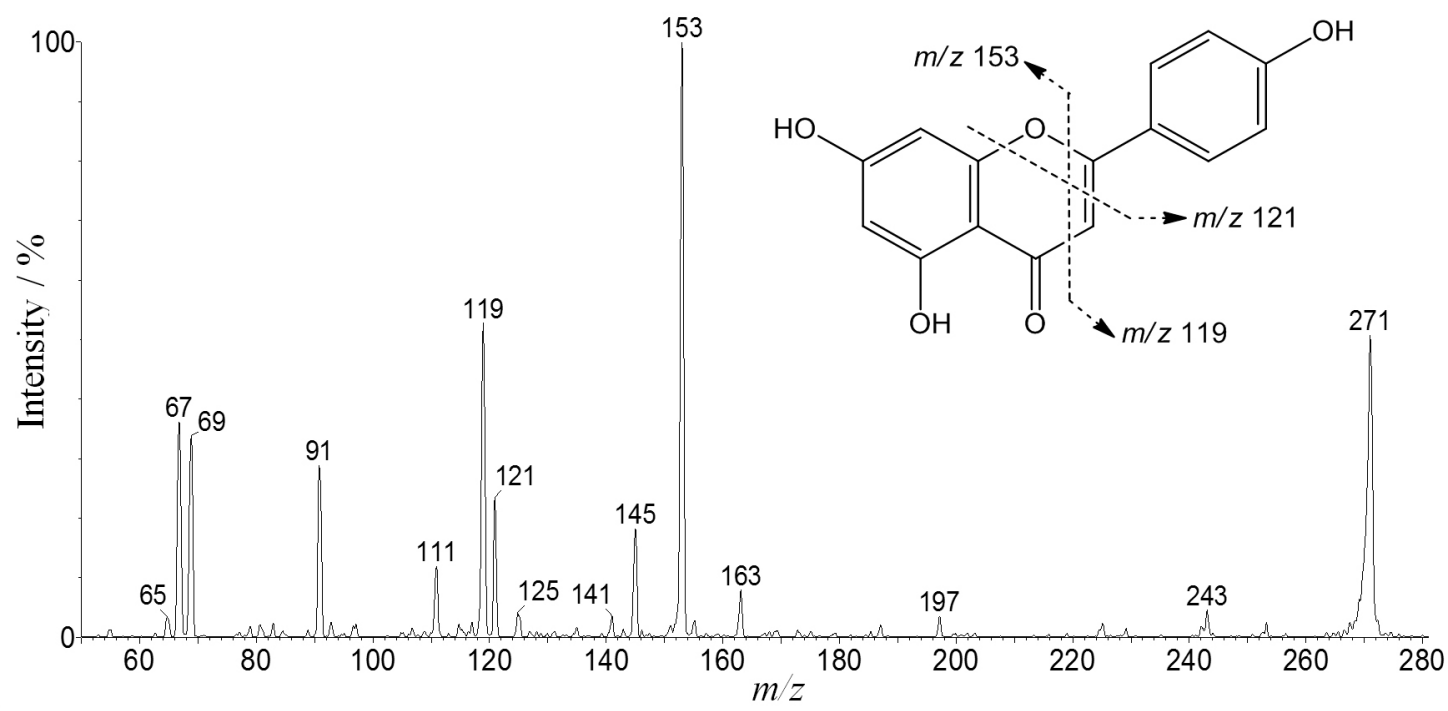

Figure 4. Ion fragmentation spectrum $[\mathrm{M}+\mathrm{H}]^{+} m / z, 271$ referring to apigenin, an oregano antioxidant. 


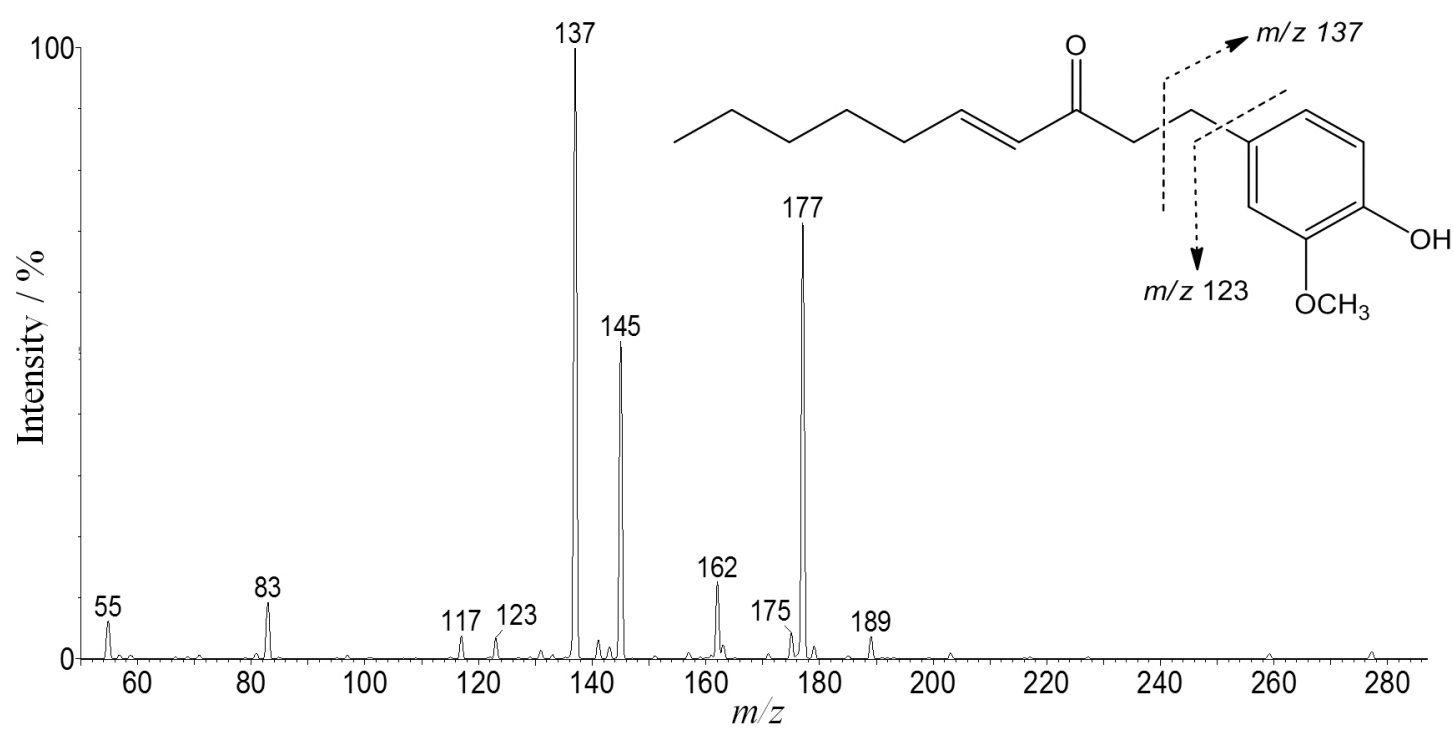

Figure 5. Ion fragmentation spectrum $[\mathrm{M}+\mathrm{H}]^{+} \mathrm{m} / z, 277$ referring to 6-shogaol, a ginger antioxidant.

Table 4. List of compounds identified in methanolic canola oil with oregano and ginger extracts

\begin{tabular}{|c|c|c|c|c|c|}
\hline & & Compound & $t_{R}{ }^{a} / \min$ & {$[\mathrm{M}+\mathrm{H}]^{+\mathrm{b}}$} & Fragments $^{\mathrm{c}}$ \\
\hline \multirow{5}{*}{ Oregano } & 1 & caffeic acid & 7.3 & 181 & $163 ; 145 ; 135 ; 117 ; 107$ \\
\hline & 2 & apigenin & 9.0 & 271 & $243 ; 163 ; 153 ; 145 ; 119 ; 91$ \\
\hline & 3 & naringenin & 9.2 & 273 & $153 ; 147 ; 123 ; 119$ \\
\hline & 4 & luteolin & 8.2 & 287 & $241 ; 153 ; 137 ; 135 ; 117$ \\
\hline & 5 & kaempferol & 11.2 & 287 & $167 ; 147 ; 119 ; 110 ; 91$ \\
\hline \multirow{4}{*}{ Ginger } & 6 & 6-shogaol & 11.3 & 277 & $177 ; 137$ \\
\hline & 7 & 6-gingerdiol & 10.8 & 297 & $177 ; 137$ \\
\hline & 8 & 8-shogaol & 12.7 & 305 & $177 ; 137$ \\
\hline & 9 & 10-shogaol & 13.5 & 333 & $177 ; 137$ \\
\hline
\end{tabular}

aRetention time; ${ }^{\mathrm{b}}$ protonated ion $\mathrm{m} / \mathrm{z}$; ${ }^{\mathrm{c}}$ daughters of parent ion fragmentation.

\section{Acknowledgments}

The authors would like to thank CAPES for financial support and Cocamar (Cooperativa Agroindustrial de Maringá), for providing canola oil.

\section{References}

1. Asensio, C. M.; Nepote, V.; Grosso, N. R.; J. Food Sci. 2012, 77, S294.

2. Kulawik, P.; Özogul, F.; Glew, R.; Özogul, Y.; J. Agric. Food Chem. 2013, 61, 475.

3. Kahl, R.; Kappus, H.; Z. Lebensm.-Unters. -Forsch. A 1993 , 196, 329.

4. Claus, T.; Maruyama, S. A.; Palombini, S. V.; Montanher, P. F.; Bonafé, E.; Junior, O. O.; Matsushita, M.; Visentainer, J. V.; LWT--Food Sci. Technol. 2015, 61, 346.

5. Xu, B. J.; Chang, S. K. C.; J. Food Sci. 2007, 72, S159.
6. Wu, X.; Beecher, G. R.; Holden, J. M.; Haytowitz, D. B.; Gebhardt, S. E.; Prior, R. L.; J. Agric. Food Chem. 2014, 52, 4026.

7. Prior, R. L.; Hoang, H.; Gu, L.; Wu, X.; Bacchiocca, M.; Howard, L.; Hampsch-Woodill, M.; Huang, D.; Ou, B.; Jacob, R.; J. Agric. Food Chem. 2003, 51, 3273.

8. Verardo, V.; Riciputi, Y.; Sorrenti, G.; Ornaghi, P.; Marangoni, B.; Caboni, M. F.; LWT--Food Sci. Technol. 2014, 50, 732.

9. Instituto Adolfo Lutz; Normas Analíticas, Métodos Químicos e Físicos para Análise de Alimento, 1ª ed.; São Paulo, 1985.

10. Jiang, H.; Sólyom, A. M.; Timmermann, B. N.; Gang, D. G.; Rapid Commun. Mass Spectrom. 2005, 19, 2957.

11. Vallverdu-Queralt, A.; Regueiro, J.; Martinez-Huelamo, M.; Alvarenga, J. F. R.; Leal, L. N.; Lamuela-Raventos, R. M.; Food Chem. 2014, 154, 299.

12. Tao, Y.; Li, W.; Liang, W.; Breeme, R. B.; J. Agric. Food Chem. 2009, 57, 10014.

13. Horai, H.; Arita, M.; Kanaya, S.; Nihei, Y.; Ikeda, T.; Suwa, 
K.; Ojima, Y.; Tanaka, K.; Tanaka, S.; Aoshima, K.; Oda, Y.; Kakazu, Y.; Kusano, M.; Tohge, T.; Matsuda, F.; Sawada, Y.; Hirai, M. Y.; Nakanishi, H.; Ikeda, K.; Akimoto, N.; Maoka, T.; Takahashi, H.; Ara, T.; Sakurai, N.; Suzuki, H.; Shibata, D.; Neumann, S.; Iida, T.; Tanaka, K.; Funatsu, K.; Matsuura, F.; Soga, T.; Taguchi, R.; Saito, K.; Nishioka, T.; J. Mass Spectrom. 2010, 45, 703 .

14. http://www.mzcloud.org, accessed in August 2016.

15. Ramalho, V. C.; Jorge, N.; Quim. Nova 2006, 29, 755.

16. Lü, J.; Lin, P. H.; Yao, Q.; Chen, C.; J. Cell. Mol. Med. 2010 , $4,840$.

17. Oroian, M.; Escriche, I.; Food Res. Int. 2015, 74, 10.
18. Bretherick, L.; Hazards in the Chemical Laboratory, $6^{\text {th }}$ ed.; Royal Society of Chemistry: Cambridge, 1994.

19. Leaf, G.; Zatman, L. J.; Brit. J. Ind. Med. 1952, 9, 19.

20. Tanaka, K.; Toda, F.; Chem. Rev. 2000, 100, 1025.

21. Plazonić, A.; Bucar, F.; Maleš, Z.; Mornar, A.; Nigović, B.; Kujundžić, N.; Molecules 2009, 14, 2466.

22. Brahmi, F.; Mechri, B.; Dabbou, S.; Dhibi, M.; Hammami, M.; Ind. Crops Prod. 2012, 38, 146.

Submitted: June 6, 2016

Published online: September 9, 2016 